\title{
Characterization of Yemeni Natural Zeolite (Al-Ahyuq Area) and its Environment Applications: A Review
}

\author{
Aref Alshameri ${ }^{1,2,3^{*}}$, Wei Xinghu ${ }^{1}$, Ammar Salman Dawood ${ }^{4,5^{*}}$, \\ Chen Xin ${ }^{1}$, ChunjieYan'2, Amer M. Assabri ${ }^{3}$ \\ 1 School of Environmental and Chemical Engineering, Foshan University, Foshan, Guangdong 528000, China \\ 2 Engineering Research Center of Nano-Geomaterial of Education Ministry, China University of Geosciences, \\ Wuhan 430074, China \\ 3 Geological Survey and Mineral Resources Board, Ministry of Oil and Minerals, Sana'a, Yemen \\ 4 College of Engineering, University of Basrah, Basrah, Iraq \\ 5 School of Environmental Studies, China University of Geosciences (Wuhan), Wuhan 430074, China \\ * Corresponding author's e-mail: aref_alshmiri@yahoo.com \& ammars.dawood@yahoo.com
}

\begin{abstract}
This research characterizes a natural zeolitic-rich tuff from Yemen (Al-Ahyuq area) and its potential in environmental applications. A total of 40 zeolite samples of Al-Ahyuq area were selected and fully characterized by a variety technique to obtain the mineralogical and physicochemical parameters. Our results show that the purities of zeolite minerals range from 78 to $\sim 100 \%$ zeolite. Clinoptilolite and mordenite are the major mineral zeolite whereas heulandite and stilbite occur in minor amounts present in the zeolite deposit. Accessory minerals include quartz, illite, mica, feldspar, kaolinite, and smectite. In addition, the chemical compositions of Al-Ahyuq zeolitic tuffs are found to be comparable with other zeolites compositions of high economic value in the world. Moreover, its environment application was also discussed in this paper.
\end{abstract}

Keywords: natural Yemeni (Al-Ahyuq) zeolite; mineralogical; chemical compositions; environment application; water treatment

\section{INTRODUCTION}

Natural zeolites gained a significant interest among the scientific community, mainly because of their abundance in surface in nature, valuable chemical/physical properties, as well as their potential application in numerous fields of industry and agricultural technology [Kesraoui Ouki et al., 1994; Papaioannou et al., 2005; Bowman, 2003]. Zeolites have been used in different sectors such as mining, gas ,petroleum processing, food, water softening, paper products and water treatment [Feng and Peng, 2005; Chen and Poon, 2009; Wang and Zhu, 2006.]. The $12^{\text {th }}$ international zeolite conference, which was held in 1998, had 774 attendees from 37 countries; there were 566 artcles and recent progress reports submitted [Jacobs et al., 2001]; thus, a growing number of researchers attending conferences and studying zeolites are just one indication that these natural materials find more and more commercial uses in a variety of diverse fields.

Natural zeolites are generally formed by the durable impacts of mineral alkaline solutions on variety of rock types of different ages at increasing temperatures. It is not astonishing that deposits of zeolite minerals are situated near volcanic craters, the environmental surroundings for which natural zeolites were formed; it reflects their particular structure and chemical composition [Moussavi et al., 2011; Townsend and Loizidou, 1984]. The natural zeolites are the crystalline, hydrated aluminosilicate of alkaline or alkaline earth metals, especially sodium, potassium, calcium, magnesium, strontium and barium, with effective physical-chemical characteristics, for 
instance, high void volume, high cation exchange capacity and cation selectivity [Kesraoui Ouki et al., 1994; Papaioannou et al., 2005]. There are approximately 50 different types of zeolites (clinoptilolite, chabazite, phillipsite, mordenite, etc.) with varying physical and chemical properties. Particle density, cation selectivity, molecular pore size, and strength are only some of the properties that can differ depending on the zeolite in question. It is important to know the specific type of zeolite one is using in order to assure that it is appropriate for one's needs. Subsequently, while developing the applications for zeolites, it is important to remember that not all of these minerals are the same. Zeolites have superior characteristics compared to other crystalline inorganic oxide-materials. For instance; they can separate molecules based on the size and configuration of the molecule relative to the size and geometry of the apertures of the zeolite structure due to the uniform and microporous pore structure within their crystals. Accordingly, they act as "molecular sieves". They also adsorb molecules which have a permanent dipole moment with selectivity not found in other adsorbents [Breck, 1984; Flanigen et al., 1991; Alshameri, 2015]. Zeolites are accessible to perform all sorts of ion exchange reactions [Townsend and Loizidou, 1984].

In a natural environment, natural zeolites usually do not occur in a pure type but typically together with other minerals and rocks. The significance is explained by extensive research centered on the properties of all-natural zeolites and choices for their particular use [Papaioannou et al., 2005; Bowman, 2003]. One of the famous types of natural zeolite is the clinoptilolite-rich tuff, it has excellent cationselectivity characteristics with high cation exchange capacity and is utilized for agricultural and environmental purposes.

Nevertheless, the literature review suggests that the zeolites from different sources have different properties affecting their adsorption ability. Each zeolite species has its own unique crystal structure and hence its own set of physical and chemical properties, attributing to the differences in the geological formation of the zeolite sources. Therefore, every special zeolite requires individual research [Bowman, 2003; Alshameri et al., 2014; Alshameri et al., 2014].

Zeolites were thoroughly studied and utilized as adsorbents, ion exchangers and acid catalysts in petrochemical and chemical companies. High safety, low cost as well as relative simplicity of application and operation are some of the attributes that are attracting an increasing focus on the use of zeolite for environment applications. Due to the nature of cation exchange, natural zeolites exhibit high performance in adsorption of cations in aqueous solution such as ammonium and heavy metals [Bowman, 2003]. The complexity of aquatic systems demands special attention in the selection and preparation of materials for water treatment. The adsorption method has several advantages compared to the other treatment processes including simplicity of operation, health-related points (no need to add chemical to water), no sludge generation, no need to pressurize water, etc. Additionally, it can be used for treatment of both contaminants cations and anions, although individually. In order for the adsorption to be effective and economical, one aspect to be considered is that the adsorbent should have high adsorption capacity and high rate [Alshameri, 2015].

However, natural zeolites show varying ion selectivity and competitive adsorption for a multi-component system. In contrast, these minerals are not good adsorbents for the adsorption of anionic ions and organics. Therefore, to remove anions from the water, zeolite surface has to be modified by inorganic salts or organic surfactants the adsorption of which on the zeolite surface leads to the formation of oxi-hydroxides, which then form stable complexes with anions in solution [Bowman, 2003; Alshameri, 2015]. In the literature, many investigations were conducted on modification of natural zeolite with either inorganic salts (for example $\mathrm{FeCl}_{3}$ ) or cationic surfactant. which led to a change in the surface charge of zeolite from negative to positive. Thus, modified zeolite increase its adsorption capacity for anions present in water [Campos and Buchler, 2007; Chmielewská et al., 2003].

In 2011, the Yemen contributed to the world supply of minerals such as celestine, clays, dolomite, feldspar, gypsum, limestone, magnesite, perlite, sandstone, scoria, talc, and zeolite. Natural zeolite occurs in altered volcanic tuffs which covered large areas $\left(>60,000 \mathrm{~km}^{2}\right)$ with volcanic ashes according to the Yemen Geological Survey and Mineral Resources Board [Schultz Grafisk, 2009]. A geological sketch map with the most promising zeolite occurrences of Yemen is shown in Figure 1. As can be seen in Figure 1, zeolitic tuff deposits in 


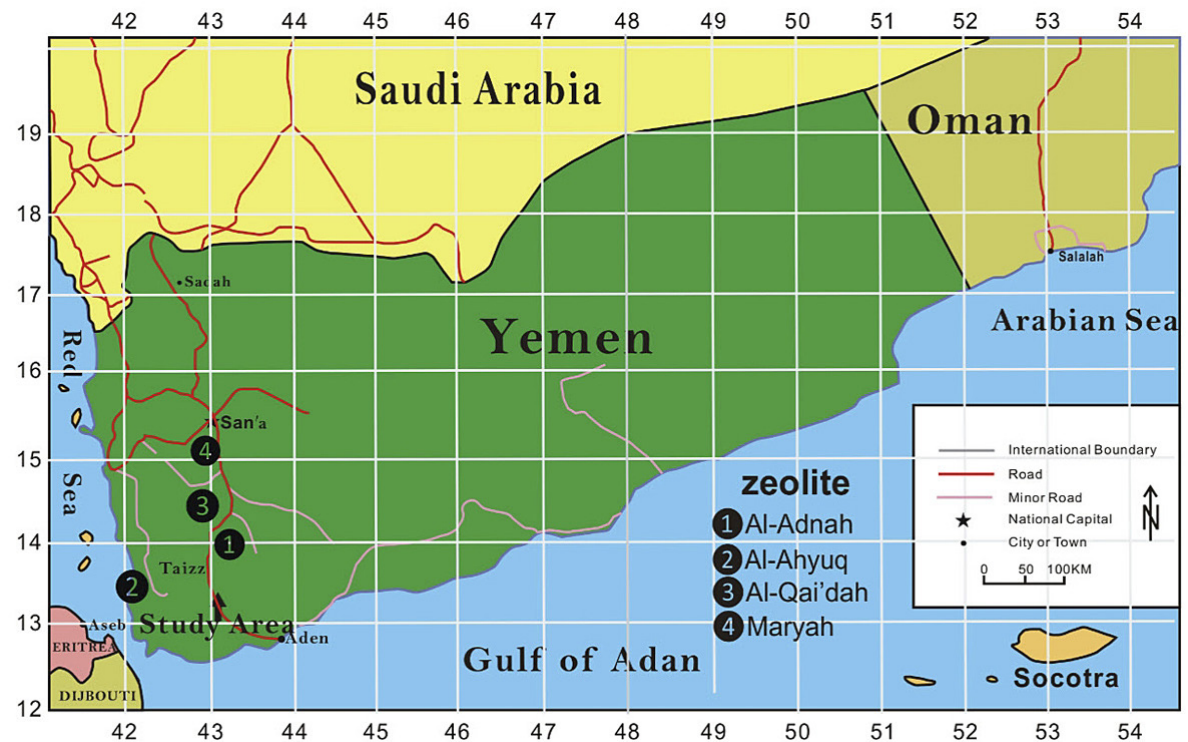

Figure 1. Geological sketch map of Yemen with the most promising zeolite occurrences.

Yemen are found in three governorates: Ta'iz, Ibb, and Dhamar [Schultz Grafisk, 2009]. These fields provide excellent targets for zeolite exploration and exploitation.

\section{Zeolite in Ta'iz}

The natural zeolite deposits in the Ta'iz governorate are found mainly in two areas (Al-Adnah and Al-Ahyuq). The zeolite minerals occur in volcanic tuffs and the kinds of natural zeolite minerals in Al-Adnah and Al-Ahyuq area are clinoptilolite, heulandites and mordinite with rare stilbite.

\section{Zeolite in Ibb}

Thenatural zeolite deposits in the Ibb governorate are found mainly in Al-Qa'idah area. They are mostly composed of clinoptilolite and heulandite.

In some areas, the zeolites are natrolite and stilbite which are found as radial crystals within cracks and voids in agglomerates.

\section{Zeolite in Dhamar}

The natural zeolite deposits in Dhamar governorate are found mainly in the Maryah area. The zeolite minerals occur in volcanic tuffs ranging from 68 to $72 \%$ zeolites. The types of natural zeolite minerals in the Maryah area are clinoptilolite, heulandite, and mordinite with rare stilbite and laomonotite.

As mentioned above, Yemen has huge reserves of high-quality zeolite deposits in three provinces; therefore it is economically considerable to perform a study on Yemeni zeolites to enable us to identify their properties and applications. Effluents from numerous industrial and agricultural activities are quickly becoming an international environmental issue. This necessitates conducting a study on a variety of liquid treatment techniques to make sure an adequate supply of potable liquid for the populace this is certainly teeming. Additionally, Yemen has limited water resources; hence, this necessitates work that is directed towards water treatment and conservation. The development of industrial activities, which are metal-based needs the option of inexpensive technology and materials for water treatment.

This research effort focuses on disclosing the mineralogical and chemical composition as well as morphology of Al-Ahyuq zeolite area and discuss its potential as an adsorbent material.

However, Al-Ahyuq zeolite is located about $89 \mathrm{~km}$ south-west of the Taiz city including $84 \mathrm{~km}$ on the road Taiz-Alberh-Allowazei and $5 \mathrm{~km}$ on the road leading to the Al-Ahyuq area. The zeolite deposits are easily accessible from both sides of the road and extend over large regions with altitudes ranging from about $680 \mathrm{~m}$ to $720 \mathrm{~m}$ above sea level [Feng and Peng, 2005].

The main objective of this work was to describe the characterization of a natural zeolitic-rich tuff from Yemen (Al-Ahyuq area). A total 40 zeolite samples of Al-Ahyuq area, about $0.5 \mathrm{~kg}$ each, was selected and examined 
to determine their mineralogical and chemical composition. The characterization of the zeolite was carried out with X-ray diffraction (XRD) and X-ray fluorescence (XRF) spectroscopy, as well as scanning electron microscopy (SEM) coupled with chemical analysis by energy dispersive spectroscopy (EDS). The chemical compositions analyzed were compared with the compositions of other zeolite deposits in the world. In addition, its potential as an adsorbent material for ammonium ion $\left(\mathrm{NH}_{4}^{+}\right)$, phosphate ion $\left(\mathrm{PO}_{4}{ }^{3-}\right)$ and $\left(\mathrm{NH}_{4}^{+}\right.$and $\left.\mathrm{PO}_{4}{ }^{3-}\right)$ removal were discussed in this chapter.

\section{MATERIAL AND ANALYTICAL METHODS}

For the purpose of the research, 40 samples of natural zeolite (NZ) were collected from Al-Ahyuq area in Taiz province, Yemen (Figure 1). NZ was crushed and the fractions which can pass through 200-230 mesh sieves were used in this study.

Identification of mineral species in the zeolite samples was carried out by means of XRD pattern using a German D8-FOCOS X-ray diffractometer with $\mathrm{Cu} \mathrm{Ka}(1=0.154 \mathrm{~nm})$ radiation operating at $40 \mathrm{kV}$ and $40 \mathrm{~mA}$ and a step width of 0.058 . Semi-quantitative weight percentages of samples were calculated by using mineral intensity factors.

The chemical compositions of the samples were tested by Netherlands, Panalytical B.V. AXIOS $^{\text {mAX }}$ X-ray fluorescence (XRF) spectroscopy. The prepared sample was fused with lithium metaborate-lithium tetraborate flux which also includes an oxidizing agent (Lithium Nitrate), and then poured into a platinum mould. The resultant disk was in turn analysed with XRF spectrometry. The XRF analysis was determined in conjunction with a loss-on-ignition at $1000^{\circ} \mathrm{C}$. The resulting data from both determinations were combined to produce the total.

The morphology of the natural zeolite was observed by using a Japanese Netherlands FESEM Quanta SU8010 electron microscope, operating at an accelerating voltage of $15 \mathrm{kV}$ for photomicrographs as well as to analyse the Yemeni zeolite composition using Energy Dispersion X-ray Spectrometry (EDS), USA, Apolloxp. The sample was initially placed in a vacuum chamber for coating with a thin layer (few nanometers) of gold (Au).

\section{RESULTS AND DISCUSSION}

\section{XRD analysis}

Quantitative analysis of the XRD results based on the diffracted intensity leads to approximate percentages of zeolite and accessory minerals. Table 1, summarized the semi-quantitative mineralogical composition for 40 samples of Al-Ahyuq zeolite. It can be seen that clinoptilolite and mordenite occur individually or in the composite, as a dominant zeolite mineral, among others (Stilbite and Heulandite). Other minor mineral phases include quartz, feldspar, kaolinite, illite, mica, and semectite. Additionally, Table 1 shows that the purity of Al-Ahyuq zeolite ranges from $78 \%$ to $\sim 100 \%$. Moreover, very low percentage of impurities such as quartz is favored in industrial and environmental applications, since it is known that impurities such as soluble silicates (e.g. quartz etc.) can affect zeolite economic value [Bowman, 2003; Ackley et al., 2003]. The results illustrated that the high purities of Al-Ahyuq zeolite have a significant potential as economic and favors in industrial and environmental applications

\section{XRF analysis}

The XRF analysis results for 40 samples of zeolitic tuffs are presented in Table 2. The chemical compositions ranged $61.01-72.00 \%$ $\mathrm{SiO} 2,10.96-14.41 \% \mathrm{Al}_{2} \mathrm{O}_{3}, 1.12-7.41 \% \mathrm{~K}_{2} \mathrm{O}$, $0.74-3.68 \% \quad \mathrm{Fe}_{2} \mathrm{O}_{3}, \quad 0.47-3.53 \% \quad \mathrm{CaO}$ and $0.47-3.53 \% \mathrm{Na}_{2} \mathrm{O}$. The chemical data show that zeolitic tuff from the Al-Ahyuq area is composed mainly of $\mathrm{SiO}_{2}$ and $\mathrm{Al}_{2} \mathrm{O}_{3}$ whereas $\mathrm{Na}_{2} \mathrm{O}, \mathrm{CaO}$, and $\mathrm{K}_{2} \mathrm{O}$ were the major single extra-framework cations in the all-natural zeolites. The major element distribution reflects the mineralogy of zeolite samples are presented in Table 1. Comparatively, the chemical compositions of Al-Ahyuq zeolitic tuffs were found to be comparable with other world zeolites compositions, as shown in Table 3. This implies that Al-Ahyuq zeolite is promising for the use of in industrial and environmental applications.

\section{SEM and EDS characterization}

The SEM and qualitative composition analysis (EDS) of the natural zeolites are shown in Figure 2. Field observation study of the samples revealed that the natural zeolite occurs mainly 
Table 1. Semi-quantitative mineralogical composition of studied Yemen's zeolite (Al- Ahyuq area)

\begin{tabular}{|c|c|c|c|c|c|c|c|c|c|c|c|}
\hline \multirow{2}{*}{$\begin{array}{c}\text { Sample. } \\
\text { NO. }\end{array}$} & \multicolumn{10}{|c|}{ Mineral composition (\%) } & \multirow[b]{2}{*}{ Total.Z\% } \\
\hline & Cp & $\mathrm{Mr}$ & St & $\mathrm{He}$ & $Q$ & $\mathrm{Fd}$ & $\mathrm{Ka}$ & 1 & $\mathrm{Mc}$ & $\mathrm{Sm}$ & \\
\hline YZ1 & 58 & 26 & 10 & - & - & - & - & - & 6 & - & 94 \\
\hline YZ2 & 54 & 23 & 20 & - & - & - & 4 & - & - & - & 97 \\
\hline YZ3 & 51 & 30 & 19 & - & - & - & - & - & - & - & 100 \\
\hline YZ4 & 61 & 27 & 12 & - & - & - & - & - & - & - & 100 \\
\hline YZ5 & 69 & 29 & - & - & - & - & - & - & - & 2 & 98 \\
\hline YZ6 & 67 & 33 & - & - & - & - & - & - & - & - & 100 \\
\hline YZ7 & 72 & 28 & - & - & - & - & - & - & - & 2 & 98 \\
\hline YZ8 & 52 & 27 & 19 & - & - & - & - & - & - & 2 & 98 \\
\hline YZ9 & 61 & 25 & 14 & - & - & - & - & - & - & - & 100 \\
\hline YZ10 & 59 & - & - & - & - & - & - & - & - & - & 59 \\
\hline YZ11 & 50 & 50 & - & - & - & - & - & - & - & - & 100 \\
\hline YZ12 & 55 & 25 & 15 & - & 5 & - & - & - & - & - & 95 \\
\hline YZ13 & 57 & 25 & 17 & - & - & - & - & - & - & 1 & 99 \\
\hline YZ14 & 64 & 21 & 15 & - & - & - & - & - & - & - & 100 \\
\hline YZ15 & 44 & 18 & 11 & 27 & - & - & - & - & - & - & 100 \\
\hline YZ16 & 55 & 25 & - & - & 3 & 17 & - & - & - & - & 80 \\
\hline YZ17 & 32 & 12 & 13 & 42 & - & - & - & 1 & - & - & 99 \\
\hline YZ18 & 55 & 22 & 17 & - & - & - & 6 & - & - & - & 94 \\
\hline YZ19 & 27 & 28 & - & - & - & - & - & - & - & - & 100 \\
\hline YZ20 & 57 & 31 & 12 & - & - & - & - & - & - & - & 100 \\
\hline YZ21 & 46 & 27 & - & - & - & 27 & - & - & - & - & 73 \\
\hline YZ22 & 68 & - & 30 & - & - & 2 & - & - & - & - & 98 \\
\hline YZ23 & 67 & 23 & 10 & - & - & - & - & - & - & - & 100 \\
\hline YZ24 & 62 & 23 & - & - & 4 & - & - & - & - & - & 85 \\
\hline YZ 25 & 56 & 37 & - & - & 7 & - & - & - & - & - & 93 \\
\hline YZ26 & 58 & 26 & 16 & - & - & - & - & - & - & - & 100 \\
\hline YZ27 & 56 & 11 & 10 & - & 4 & - & - & 19 & - & - & 77 \\
\hline YZ28 & 50 & 20 & 11 & - & - & - & - & 9 & - & 10 & 81 \\
\hline YZ29 & 58 & 26 & 16 & - & - & - & - & - & - & - & 100 \\
\hline YZ30 & 52 & 28 & 20 & - & - & - & - & - & - & - & 100 \\
\hline YZ31 & 51 & 24 & 17 & - & - & - & 8 & - & - & - & 92 \\
\hline YZ32 & 64 & 33 & - & - & 3 & - & - & - & - & - & 97 \\
\hline YZ33 & 94 & - & - & - & 6 & - & - & - & - & - & 94 \\
\hline YZ34 & 62 & 38 & - & - & - & - & - & - & - & - & 100 \\
\hline YZ35 & 42 & - & - & 16 & 4 & 37 & - & - & - & - & 59 \\
\hline YZ36 & 52 & 24 & - & 21 & 4 & - & - & - & - & - & 96 \\
\hline YZ 37 & 65 & - & 30 & - & 3 & - & - & - & - & 2 & 95 \\
\hline YZ 38 & 52 & 24 & 19 & - & 4 & - & - & - & - & - & 96 \\
\hline YZ 39 & 25 & 11 & 10 & - & 11 & - & 42 & - & - & - & 46 \\
\hline YZ 40 & 53 & - & - & - & 7 & - & 39 & - & - & - & 53 \\
\hline
\end{tabular}

Note: Q: quartz, Cp: Clinoptilolite, Mr: Mordenite, St: Stilbite, He: Heulandite, Fd: Feldspar, Ka: Kaolinite, I: Illite, Mc: Mica, Sm: Semectite

as well-formed fine sized crystals. The typical characteristic morphology of the natural zeolites shows a tabular morphology, as expected for a (monoclinic) clinoptilolite (Figure 2).
The EDS spectra (Figure 2) revealed the existence of the following elements $\mathrm{Al}, \mathrm{Si}, \mathrm{O}, \mathrm{Na}, \mathrm{Mg}$, $\mathrm{K}, \mathrm{Ca}$ and $\mathrm{Fe}$ which were present in the structure of the natural zeolite and in agreement with the 
Table 2. The chemical composition of the analyzed samples of studied Yemen's zeolite (Al- Ahyuq area)

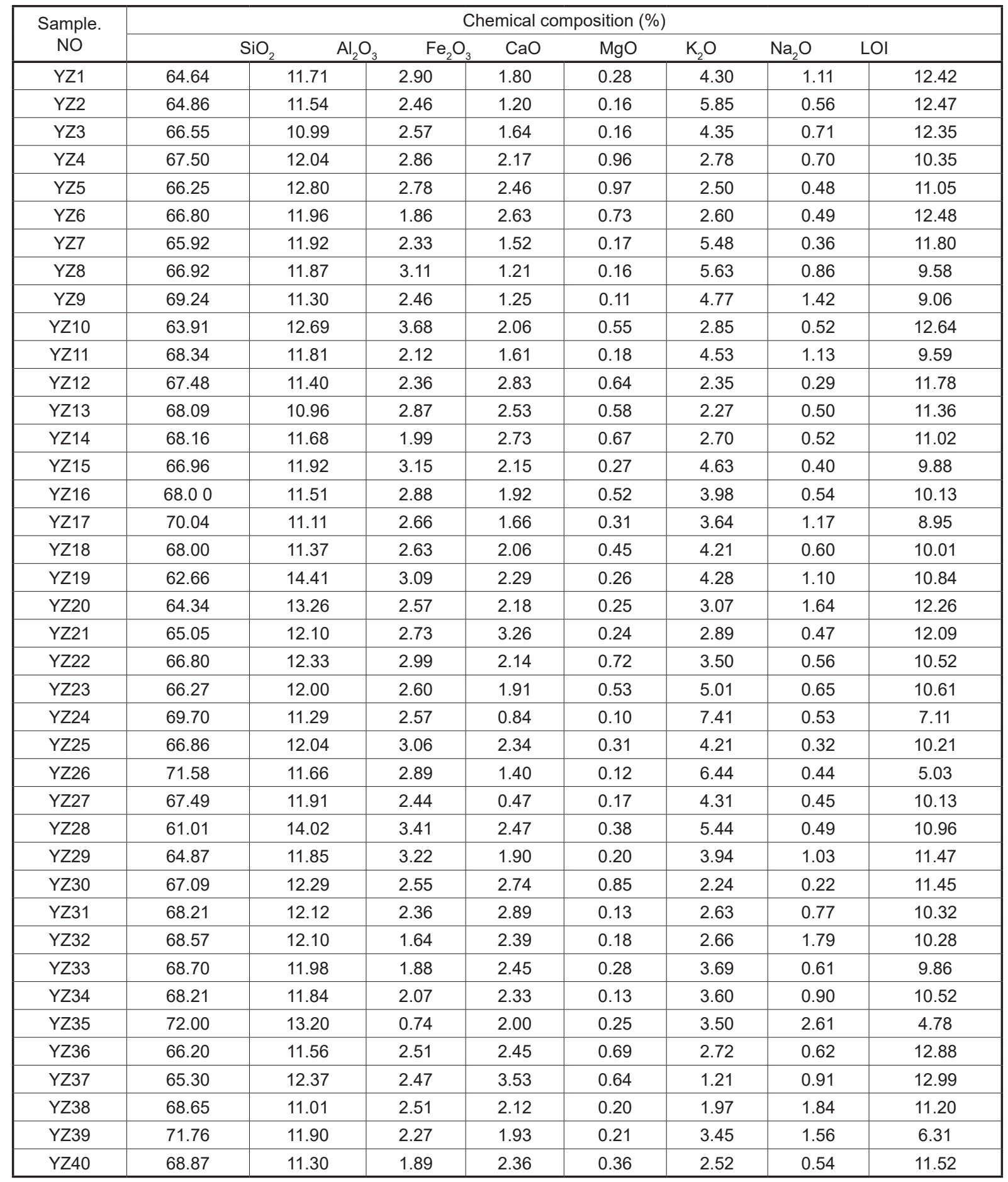

Table.3 The chemical composition of natural zeolite in the world.

\begin{tabular}{|c|c|c|c|c|c|c|c|c|c|}
\hline \multirow{2}{*}{ Sample } & \multicolumn{8}{|c|}{ Chemical composition (\%) } & \multirow{2}{*}{ Reference } \\
\hline & $\mathrm{SiO}_{2}$ & $\mathrm{Al}_{2} \mathrm{O}_{3}$ & $\mathrm{Fe}_{2} \mathrm{O}_{3}$ & $\mathrm{CaO}$ & $\mathrm{MgO}$ & $\mathrm{Na}_{2} \mathrm{O}$ & $\mathrm{K}_{2} \mathrm{O}$ & $\mathrm{TiO}_{2}$ & \\
\hline Turkey & 70.90 & 12.40 & 1.21 & 2.54 & 0.83 & 0.28 & 4.46 & 0.09 & [19] \\
\hline Chinese & 65.52 & 9.89 & 1.04 & 3.17 & 0.61 & 2.31 & 0.88 & 0.21 & [20] \\
\hline Australian & 68.26 & 12.99 & 1.37 & 2.09 & 0.83 & 0.64 & 4.11 & 0.23 & [6] \\
\hline Croatian & 55.80 & 13.32 & 1.30 & 5.75 & 0.70 & 3.90 & 2.35 & - & [21] \\
\hline Slovakian & 67.16 & 12.30 & 2.30 & 2.91 & 1.10 & 0.66 & 2.28 & 0.17 & [21] \\
\hline USA & 66.80 & 11.30 & 0.97 & 0.79 & 0.33 & 3.60 & 3.74 & - & [21] \\
\hline
\end{tabular}



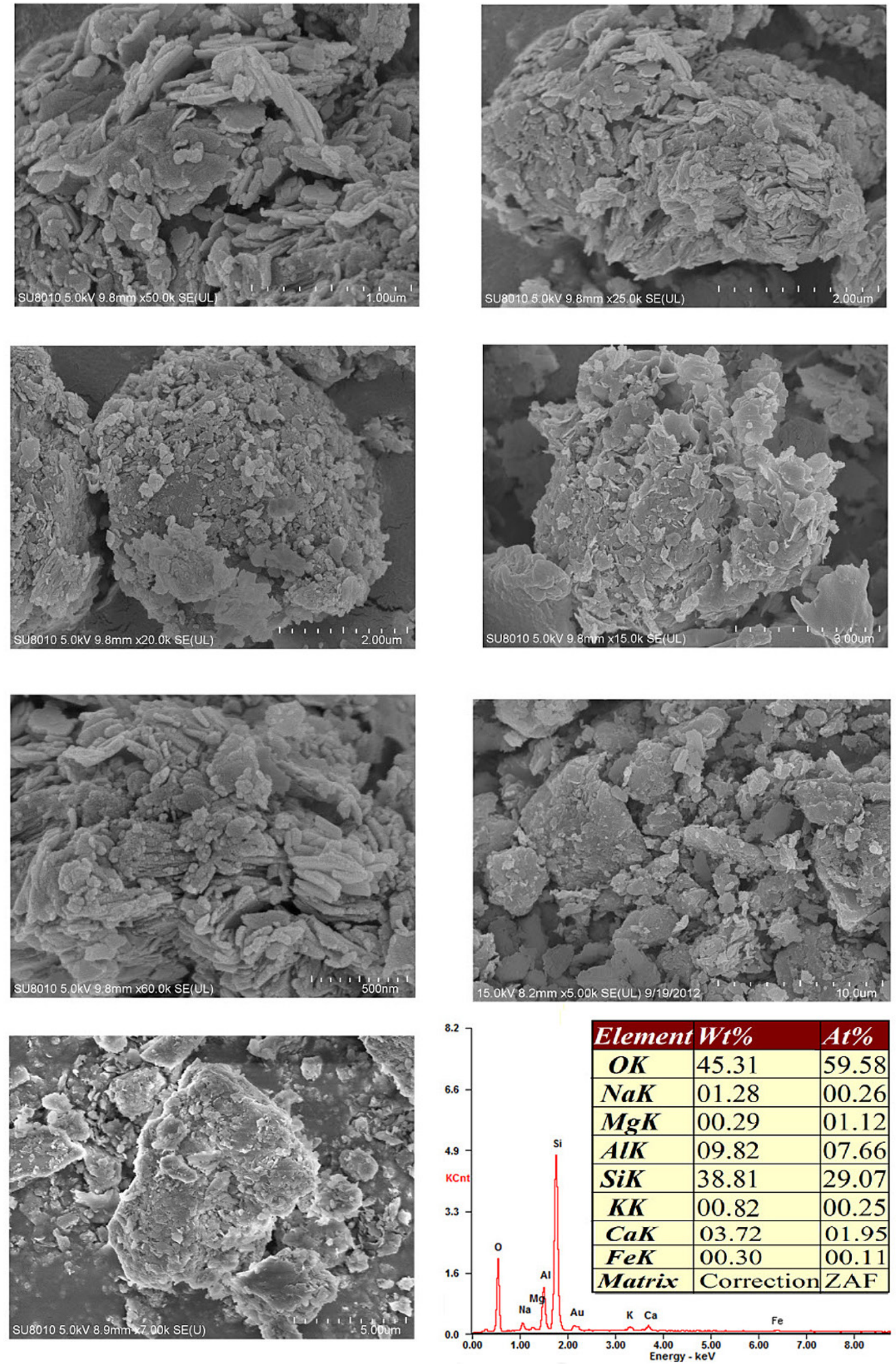

Figure 2. SEM and analysis (EDS) of studied Yemen's zeolite (Al-Ahyuq area) 
results obtained from XRF, as given in Table 2. Consequently, based on the high purity of Yemeni zeolitic tuffs, the minority of impurities such as quartz, zeolite morphology and its comparability with other world deposits of high economic value gives Al-Ahyuq zeolite high potential for use in water treatment. It can be concluded that the natural zeolite of Al- Ahyuq area seems to be more viable for use in environmental applications.

\section{Al- Ahyuq zeolite as effective adsorbents in water treatment}

Natural zeolites are classified as low-cost adsorbents because of their local availability and low-cost of extraction and preparation. The world is currently facing a water crisis due to lack of clean drinking water. The rapid development of several industries has led to the discharge of huge quantity of wastewater into soils and surface water [Moussavi et al., 2011; Alshameri et al., 2014].

Natural zeolites are hydrated aluminosilicate minerals with three dimensional framework structure bearing $\mathrm{AlO}_{4}$ and $\mathrm{SiO}_{4}$ tetrahedra. These are linked to each other by sharing all of the oxygen to form interconnected cages and channels [Tschernich, 1992; Taffarel and Rubio, 2009].

Each aluminum atom $\left(\mathrm{Al}^{3+}\right)$ substitution for silicon $\left(\mathrm{Si}^{4+}\right)$ in the zeolite framework generates one negative charge on the framework. The higher the negative charge of zeolite, the greater the $\mathrm{Al}^{3+}$ substitution [Nguyen and Tanner, 1998; Polat et al., 2004]. The negative charge is balanced by positively charged (cations) like $\mathrm{Na}^{+}$, $\mathrm{K}^{+}, \mathrm{Ca}^{2+}, \mathrm{Mg}^{2+}$ on the external surface of zeolite [Rožić et al., 2000]. These cations are bound with aluminosilicate structure by weaker electrostatic bonds that cause the ability of being exchanged with certain cations in solutions [Wang and Peng, 2010]. These unique structures of natural zeolites, give rise to high cation-exchange capacity adsorption and molecular sieve capabilities [Alshameri, 2015].

Eutrophication is a major problem of surface water, resulting primarily from the phosphate and ammonium pollution [Huo et al., 2012]. Phosphate and ammonium ions are major components of most fertilizers and detergents. More often than not, these chemicals find their way into water bodies either through run-off or direct discharge from industries [Alshameri et al., 2014; Alshameri et al., 2017]. When the concentration exceeds the threshold needed by the aquatic environment, eutrophication occurs, thereby threatening the ecosystem [Wang and Peng, 2010; Mena-Duran et al., 2007]. This is as a result of the explosion of the algal population due to increase in nutrients $\left(\mathrm{NH}_{4}^{+}\right.$and $\left.\mathrm{PO}_{4}^{3-}\right)$ which then deprive another aquatic organism of oxygen supply and sometimes also releases toxins into the environment [Haghseresht et al., 2009, Jentys and Lercher, 2001]. Therefore, the removal of $\mathrm{NH}_{4}^{+}$and $\mathrm{PO}_{4}^{3-}$ from industrial wastewater prior to discharge into surface water is obligatory. However, the possibility of the ammonium and phosphate removal from Al-Ahyuq zeolite as single and binary has been investigated in detail [Alshameri et al., 2014, Alshameri et al., 2014, Alshameri et al., 2017].

\section{$4 \mathrm{NH}_{4}^{+}$Removal}

This research presented Al-Ahyuq natural zeolite and its modified form ( $\mathrm{Na}^{+}$Zeolite) for the effectiveness of $\mathrm{NH}_{4}^{+}$removal from aqueous solution. The results show that the modified Al-Ahyuq natural zeolite has a high selectivity for $\mathrm{NH}_{4}^{+}$and has a maximum removal efficiency reaching up to $99 \%$ based on relevant parameters. Hence, the higher ion exchange capacity of $\mathrm{Na}^{+}$Zeolite was verified in accordance with natural one. It was also noted that the highest ion exchange capacity was obtained at $35^{\circ} \mathrm{C}$ and $\mathrm{pH}$ of 8 [Alshameri et al., 2014]. Additionally, it was found that $120 \mathrm{~min}$ and $20 \mathrm{~min}$ are needed for the equilibrium ion exchange for $\mathrm{NH}_{4}^{+}$removal on natural and modified zeolite, respectively.

Moreover, the ion exchange kinetics of $\mathrm{NH}_{4}^{+}$ by both $\mathrm{NZ}$ and SNZ were reported [Alshameri et al., 2014]. The kinetic data were much better fitted by the pseudo second-order model than the other models (pseudo first-order model and Bangham model), whereas the isotherms were fitted to the Langmuir model that a very good fit to the Langmuir isotherm model [Alshameri et al., 2014]. This study concluded the Al-Ahyuq modified natural zeolite has significant potential as an economic and effective adsorbent material for ammonium removal from aqueous solutions [Alshameri et al., 2014].

\section{$\mathrm{PO}_{4}^{3-}$ Removal}

Yemeni Al-Ahyuq natural zeolite has been modified by $\mathrm{TiO}_{2}$ and used for phosphate ion $\left(\mathrm{PO}_{4}^{3-}\right)$ removal [Alshameri et al., 2014]. The study reported that the specific surface area and 
$\mathrm{PO}_{4}^{3-}$ adsorption capacity of the composite material after modification reached $166.5 \mathrm{~m}^{2} / \mathrm{g}$ and $37.6 \mathrm{mg} / \mathrm{g}$, respectively. The study reveals that the adsorption of $\mathrm{PO}_{4}{ }^{3-}$ by $\mathrm{TiO}_{2}$-zeolite was very fast, $98.5 \%$ of $\mathrm{PO}_{4}{ }^{3-}$ was removed within $5 \mathrm{~min}$ [Alshameri et al., 2014]. It was also found that $120 \mathrm{~min}$ and $5 \mathrm{~min}$ are required for the equilibrium adsorption to be attained for natural and $\mathrm{TiO}_{2}$-zeolite, respectively, and maximum adsorption occurred at around $\mathrm{pH} 2-4$ and $35^{\circ} \mathrm{C}$. this study concluded that a $\mathrm{TiO}_{2} /$ Zeolite composite is a highly efficient and economic adsorbent material with good regeneration and can be utilized in the remediation of environmental pollution [Alshameri et al., 2014].

\section{$\mathrm{NH}_{4}^{+}$and $\mathrm{PO}_{4}^{3-}$ Removal}

In this study, Al-Ahyuq, natural zeolite was modified $\mathrm{NaCl}, \mathrm{AlCl}_{3}$ and thermal treatment for the removal of $\mathrm{NH}_{4}^{+}$and $\mathrm{PO}_{4}^{3-}$ ions [Alshameri et al., 2017]. The study shows when natural zeolite activated with the $1 \mathrm{M} \mathrm{NaCl}$ and $10 \mathrm{~cm} \mathrm{(3)/g} \mathrm{of}$ pillaring dosage, $97.80 \%$ for $\mathrm{NH}_{4}^{+}$and $98.60 \%$ for $\mathrm{PO}_{4}^{3-}$ were removed. The result indicated that the $\mathrm{Na}^{+}$exchange is the main mechanism for $\mathrm{NH}_{4}^{+}$removal, whereas the adsorption mechanism for $\mathrm{PO}_{4}^{3-}$ the result of $\mathrm{Al}-\mathrm{OH}$ groups present in the modified zeolite. It was also noted that the Gibbs free energy change for the simultaneous removal of the ions indicates that $\mathrm{NH}_{4}^{+}$is adsorbed faster compared to $\mathrm{PO}_{4}^{3-}$. It was concluded that the simultaneous removal of $\mathrm{NH}_{4}^{+}$and $\mathrm{PO}_{4}{ }^{3-}$ by modified Al-Ahyuq natural zeolite is cost-effective in water treatment at low ion concentrations [Alshameri et al., 2017].

From the discussion above, it was evident that Al-Ahyuq natural zeolite is promising for the use in water treatment.

\section{CONCLUSION}

Having characterized the natural zeolites from the Al-Ahyuq area by X-ray diffraction, $\mathrm{X}$-ray fluorescence, SEM, and evaluated its potential in the environmental applications, the following conclusions were drawn from this study: the results indicated that the zeolitic tuffs of the AlAhyuq area contain zeolite minerals in the range $78 \%$ to $\sim 100 \%$ with accessory minerals such as quartz, feldspar, kaolinite, illite, mica, and semectite. The chemical compositions of Al-Ahyuq zeolite were comparable with zeolite deposits of high economic value in the world. SEM shows that the natural zeolite is a tabular morphology, as expected for a (monoclinic) clinoptilolite and the EDS results are consistent with the data obtained from XRF. In addition, on the basis of bulk mineralogical properties, bulk chemical composition, zeolites morphology and its high purities illustrated that the Al-Ahyuq zeolites can potentially be used not only for environmental applications but also in industrial applications. This study reveals the role of natural zeolite of Al-Ahyuq as effective adsorbents for the ammonium and phosphate as single and binary components from aqueous solution. In this respect, it is important to continue with the research aimed at identifying its potential for industrial applications as well as further work should be extended to the adsorption of other pollutants. However, further study is necessary to establish the process parameters to generate better quality of products.

\section{Acknowledgements}

The authors wish to thank the Geological Survey and Mineral Resources Board, Sana'a, Yemen, and Engineering Research Center of Nano-Geomaterials of Education Ministry, China University of Geosciences, Wuhan430074, China, for financial and technical support.

\section{REFERENCES}

1. Ackley, M.W., Rege, S.U. and Saxena, H., 2003. Application of natural zeolites in the purification and separation of gases. Microporous and Mesoporous Materials, 61(1-3), 25-42.

2. Alpat, S.K., Özbayrak, Ö., Alpat, Ş. and Akçay, H., 2008. The adsorption kinetics and removal of cationic dye, Toluidine Blue $\mathrm{O}$, from aqueous solution with Turkish zeolite. Journal of hazardous materials, 151(1), 213-220.

3. Alshameri A., 2015. Research on Yemeni and Huludao Zeolite as Adsorbent Material for $\mathrm{NH}_{4}^{+}$and PO43-.Thesis. China University of Geosciences.

4. Alshameri, A., He, H., Dawood, A.S. and Zhu, J.I.A.N.X.I., 2017. Simultaneous removal of $\mathrm{NH}_{4}^{+}$ and $\mathrm{PO}_{4}^{3-}$ from simulated reclaimed waters by modified natural zeolite. Preparation, characterization and thermodynamics. Environment Protection Engineering, 43(4).

5. Alshameri, A., Ibrahim, A., Assabri, A.M., Lei, X., Wang, H. and Yan, C., 2014. The investigation into the ammonium removal performance of Ye- 
meni natural zeolite: Modification, ion exchange mechanism, and thermodynamics. Powder Technology, 258,.20-31.

6. Bowman, R.S., 2003. Applications of surfactant-modified zeolites to environmental remediation. Microporous and mesoporous materials, 61(1-3), 43-56.

7. Breck, D.W., 1984. Zeolite molecular sieves: structure, chemistry and use. Krieger.

8. Campos, V. and Buchler, P.M., 2007. Anionic sorption onto modified natural zeolites using chemical activation. Environmental geology, 52(6), 1187-1192.

9. Chen, J. and Poon, C.S., 2009. Photocatalytic construction and building materials: from fundamentals to applications. Building and environment, 44(9), 1899-1906.

10. Chmielewská, E., Jesenák, K. and Gáplovská, K., 2003. Arsenate and chromate removal with cationic surfactant-loaded and cation-exchanged clinoptilolite-rich tuff vs montmorillonite. Collection of Czechoslovak chemical communications, 68(4), 823-836.

11. Du, Q., Liu, S., Cao, Z. and Wang, Y., 2005. Ammonia removal from aqueous solution using natural Chinese clinoptilolite. Separation and purification technology, 44(3), 229-234.

12. Feng, N.Q. and Peng, G.F., 2005. Applications of natural zeolite to construction and building materials in China. Construction and Building Materials, 19(8), 579-584.

13. Flanigen, E.M., Jansen, J.C. and van Bekkum, H. eds., 1991. Introduction to Zeolite Science and Practice (Vol. 58). Elsevier.

14. Haghseresht, F., Wang, S. and Do, D.D., 2009. A novel lanthanum-modified bentonite, Phoslock, for phosphate removal from wastewaters. Applied Clay Science, 46(4), 369-375.

15. Huo, H., Lin, H., Dong, Y., Cheng, H., Wang, H. and Cao, L., 2012. Ammonia-nitrogen and phosphates sorption from simulated reclaimed waters by modified clinoptilolite. Journal of hazardous materials, 229, 292-297.

16. Jacobs, P.A., Flanigen, E.M., Jansen, J.C. and van Bekkum, H., 2001. Introduction to zeolite science and practice (Vol. 137). Elsevier.

17. Jentys, A. and Lercher, J.A., 2001. Techniques of zeolite characterization. Studies in Surface Science and Catalysis, Vol. 137, 345-386.

18. Kesraoui- Ouki, S., Cheeseman, C.R. and Perry, R., 1994. Natural zeolite utilisation in pollution control: A review of applications to metals' effluents. Journal of Chemical Technology \& Bio- technology: International Research in Process, Environmental AND Clean Technology, 59(2), 121-126.

19. Mena-Duran, C.J., Kou, M.S., Lopez, T., AzamarBarrios, J.A., Aguilar, D.H., Dominguez, M.I., Odriozola, J.A. and Quintana, P., 2007. Nitrate removal using natural clays modified by acid thermoactivation. Applied Surface Science, 253(13), 5762-5766.

20. Moussavi, G., Talebi, S., Farrokhi, M. and Sabouti, R.M., 2011. The investigation of mechanism, kinetic and isotherm of ammonia and humic acid co-adsorption onto natural zeolite. Chemical Engineering Journal, 171(3), 1159-1169.

21. Nguyen, M.L. and Tanner, C.C., 1998. Ammonium removal from wastewaters using natural New Zealand zeolites. New Zealand Journal of Agricultural Research, 41(3), 427-446.

22. Papaioannou, D., Katsoulos, P.D., Panousis, N. and Karatzias, H., 2005. The role of natural and synthetic zeolites as feed additives on the prevention and/or the treatment of certain farm animal diseases: a review. Microporous and mesoporous materials, 84(1-3), 161-170.

23. Polat, E., Karaca, M., Demir, H. and Onus, A.N., 2004. Use of natural zeolite (clinoptilolite) in agriculture. Journal of fruit and ornamental plant research, 12(1), 183-189.

24. Rožić, M., Cerjan-Stefanović, Š., Kurajica, S., Vančina, V. and Hodžić, E., 2000. Ammoniacal nitrogen removal from water by treatment with clays and zeolites. Water Research, 34(14), 3675-3681.

25. Schultz Grafisk, 2009. Zeolite in Yemen, Exploration and mining in Yemen by Yemen Geological Survey and Mineral Resources Board, Yemen.

26. Taffarel, S.R. and Rubio, J., 2009. On the removal of $\mathrm{Mn}^{2+}$ ions by adsorption onto natural and activated Chilean zeolites. Minerals Engineering, 22(4), 336-343.

27. Townsend, R.P. and Loizidou, M., 1984. Ion exchange properties of natural clinoptilolite, ferrierite and mordenite: 1 . Sodium-ammonium equilibria. Zeolites, 4(2), 191-195.

28. Tschernich, R.W., 1992. Zeolites of the world, pp. 563.

29. Wang, S. and Peng, Y., 2010. Natural zeolites as effective adsorbents in water and wastewater treatment. Chemical Engineering Journal, 156(1), 11-24.

30. Wang, S. and Zhu, Z.H., 2006. Characterisation and environmental application of an Australian natural zeolite for basic dye removal from aqueous solution. Journal of hazardous materials, 136(3), 946-952. 